\title{
Analisis Kemampuan Literasi Statistis Peserta Asesmen Kompetensi Minimum (AKM)
}

\author{
Bayu Irwandi ${ }^{1 *}$, Yenita Roza ${ }^{2}$, Maimunah ${ }^{3}$ \\ 1,2,3 Universitas Riau, Kota Pekanbaru, Riau 28293, Indonesia
}

Pengiriman: 13/September/2021; Diterima: 24/September/2021; Publikasi: 30/September/2021

DOI: https://doi.org/10.31629/jg.v6i2.3961

\begin{abstract}
Abstrak
Kemampuan literasi statistis merupakan salah satu aspek penting yang perlu dimiliki oleh peserta AKM. Pembelajaran statistika menjadi Salah satu usaha yang dapat dilakukan guru dalam membangun kemampuan literasi statistis siswa. Artikel ini bertujuan untuk mendeskripsikan kemampuan literasi statistis peserta AKM, serta mengetahui gambaran kesulitan yang dialami oleh peserta didik dalam menyelesaikan masalah yang berkaitan dengan konsep statistika. Penelitian ini dilakukan dengan menggunakan pendekatan kualitatif dengan metode deskriptif. Subjek penelitian adalah sebanyak 45 siswa peserta AKM di SMK Abdurrab Pekanbaru tahun 2021. Teknik pengumpulan data dilakukan dengan menggunakan instrument tes kemampuan literasi statistis dengan cakupan materi tes yaitu materi statistika. Penelitian ini menghasilkan perolehan persentase kemampuan literasi statistis peserta didik yang masih rendah disetiap indikatornya. Kemampuan peserta didik pada indikator menginterpretasikan data memiliki persentase terbesar, yaitu $57,78 \%$. Dan pada indikator menyajikan data memperoleh persentase paling rendah, yaitu $35,56 \%$. Sebagian peserta didik masih belum dapat memahami konsep statistika dengan baik sehingga tidak mampu menyajikan data dan memberikan kesimpulan statistic dengan tepat.
\end{abstract}

Kata Kunci: literasi statistis; pembelajaran matematika; asesmen kompetensi minimum

\begin{abstract}
Statistical literacy is an important aspect that is required for AKM participants. The alternative way in building statistical literacy skills is through learning mathematics, especially in statistics material. The aim of this article is to describe the statistical literacy skills of AKM participants, as well as to describe the difficulties experience faced by the participants in solving problems related to statistical consepts. This research was conducted using a qualitative approach with a descriptive method. The subjects of this study were 45 students who is participating in the AKM at SMK Abdurrab Pekanbaru in 2021. The data collection technique was carried out using a statistical literacy test instrument with the scope of the best material, namely statistical material. This study resulted in the acquisition of statistical literacy ability of students who were still lower in each indicator. The ability of students in the indicator to interpret was the largest percentage, with the percentage $57.78 \%$. And for the indicator to present the data was the lowest percentage, with the percentage $35.56 \%$. some students still cannot understand statistical concepts, so they are not able to present the right data anda coclusions appropriately.
\end{abstract}

Keywords: literacy statistics, mathematics learning, minimum competency assessment

\section{Pendahuluan}

Pada saat ini, situasi pandemi covid-19 telah menuntut adanya perubahan dalam konteks pembelajaran. Sebagai salah satu usaha dalam membangun kecakapan hidup selama melalui masa pandemic, para peserta didik perlu dibekali dengan kemampuan memilih informasi, menganalisis informasi dengan kritis, serta 
JURNAL GANTANG. September 2021; VI(2): 177 - 183

p-ISSN. 2503-0671

e-ISSN. 2548-5547

menggunakan informasi tersebut untuk mengambil keputusan yang diperlukan dalam kehidupan (Kemendikbud, 2020). Sejalan dengan hal tersebut, Fitni, Yenita Roza, \& Maimunah (2020) mengungkapkan bahwa kurangnya kemampuan siswa dalam memahami informasi mengakibatkan siswa mengalami kesalahan dalam melakukan penyelesaian masalah. Lebih lanjut Siskawati, dkk (2021) mengungkapkan bahwa masa pandemi virus corona merupakan masa dimana ilmu pengetahuan dan teknologi berkembang dengan cepat, sehingga kemampuan dasar yang harus dimiliki oleh peserta didik tidak hanya sekedar kemampuan membaca, menulis, dan berhitung melainkan kemampuan memahami teknologi, memahami informasi yang ditampilkan dalam bentuk numerik dan grafik, serta berpikir kritis terhadap informasi atau data yang dibaca. Hal-hal yang mengacu pada kemampuan dasar tersebut adalah jenis kemampuan literasi statistis, yang penting untuk dikuasai siswa (Fadillah and Munandar 2021).

Kemampuan literasi statistis merupakan suatu kemampuan dalam melakukan interpretasi, evaluasi kritis, dan komunikasi informasi serta pesan statistik (Gal, 2002; Gal dalam Sharma, 2017). Literasi statistis meliputi kemampuan pemahaman dan penggunakan bahasa dasar dan alat dari statistik (Garfield et al., 2010). Lebih lanjut, Garfield (Rumsey, 2002) menjelaskan secara spesifik bahwa kemampuan literasi statistis meliputi kemampuan dalam menginterpretasikan grafik dan mampu dalam membaca dan memahami statistika yang tersaji dalam media masa. Lebih lanjut kemampuan literasi melibatkan dua kemampuan membaca, yaitu pemahaman dan interpretasi (Maryati \& Priatna, 2018). Ini berarti, secara sederhana, kemampuan literasi merupakan kemampuan dalam memahami simbol- symbol statistic serta menginter pretasikannya.

Sejalan dengan definisi diatas, dikatakan bahwa kemampuan literasi statistik merupakan kemampuan untuk memahami, interpretasi, evaluasi, dan komunikasi data statistik melalui berbagai media secara kritis (Yuniawatika 2018). Dijelaskan lebih lanjut, kemampuan memahami

meliputi pemahaman mengenai simbol, bahasa statistik, tampilan data dalam bentuk garfik atau tabel, dan membuat hubungan antar data statistik. Kemampuan interpretasi dan evaluasi meliputi kemampuan pemahaman seseorang untuk membaca data dan menganalisisnya berdasarkan pada pengetahuan statistika yang sudah ada sebelumnya, sehingga dapat dilakukan prediksi secara umum (Andriatna et al. n.d.).

Salah satu upaya membangun kemampuan literasi statistis siswa dapat dikembangkan melalui penguasaan matematika pada materi statistika. Dengan memahami materi statistika, siswa dapat memahami cara mengumpulkan informasi dan penarikan kesimpulan berdasarkan analisis data statistika yang dilakukannya (Fadillah and Munandar 2021). Bahkan Kementerian Pendidikan menjadikan materi statistika sebagai salah satu materi yang diujikan pada Asesmen Kompetensi Minimum (AKM) untuk mengukur tingkat literasi numerasi siswa (Pusmenjar, 2021).

Asesmen Kompetensi Minimum (AKM) merupakan bagian dari Asesmen Nasional (AN) yang akan dilaksanakan pada tahun 2021 ini. AKM merupakan penilaian kompetensi mendasar yang diperlukan oleh semua murid untuk mampu mengembangkan kapasitas diri dan berpartisipasi positif pada masyarakat. Terdapat dua kompetensi mendasar yang diukur AKM yaitu literasi membaca dan literasi matematika (numerasi). Baik pada literasi membaca dan numerasi, kompetensi yang dinilai mencakup keterampilan berpikir logis-sistematis, keterampilan bernalar menggunakan konsep serta pengetahuan yang telah dipelajari, serta keterampilan memilah serta mengolah informasi (Pusmenjar 2021).

Salah satu upaya yang bisa dilakukan oleh guru untuk menyiapkan siswanya dalam melaksanakan AKM adalah dengan membekali kemampuan literasi statistik pada siswanya. Hal ini dikarenakan materi statistika menjadi salah satu materi yang diujikan pada AKM dan juga karena salah satu keterampilan yang dinilai pada AKM ini adalah keterampilan memilah serta mengolah informasi, yang mana keterampilan ini 
erat kaitannya dengan indikator kemampuan literasi statistis.

Dalam hal membekali kemampuan literasi statistis siswa, guru sebaiknya memberikan kesempatan kepada siswa untuk mengembangkan pemahaman statistiknya dan mendorong siswa untuk membangun pengetahuan matematika sendiri melalui pemecahan masalah praktis dalam berbagai macam konteks kehidupan sehari-hari, yang berkaitan dengan memahami, mengelola, menganalisis informasi yang ditampilkan dalam berbagai bentuk grafik, tabel, bagan, dan sebagainya lalu mampu menginterpretasikannya (Fadillah and Munandar 2021). Namun, penelitian tentang kemampuan literasi statistis yang telah dilakukan Maryati \& Priatna (2018) menunjukkan bahwa tingkat kemampuan literasi statistis peserta didik di Madrasah Tsanawiyah masih tergolong rendah karena belum mencapai kriteria ketuntasan minimum. Dengan presentase yang masih kecil disetiap indikator, khususnya pada indikator kemampuan mempresentasikan hasil pengolahan data statistika. Penelitian lainnya juga dilakukan oleh Fadillah \& Munandar (2021) yang menunjukkan perolehan presentase kemampuan literasi statistis peserta didik kelas $\mathrm{X}$ di SMAN 1 Setu Bekasi yang masih rendah di setiap indikatornya.

Berkaitan dengan masalah tersebut, maka perlu adanya penelitian untuk mengetahui bagaimana kemampuan literasi statistis peserta didik yang akan mengikuti AKM. Pentingnya penelitian ini dilakukan untuk melihat bagaimana gambaran kemampuan literasi statistis pada peserta didik yang akan mengikuti AKM. Dengan demikian, guru dapat mengambil tindakan dalam upaya meningkatkan kemampuan literasi statistis peserta didik sebagai salah satu langkah untuk persiapan menghadapi AKM. Oleh karena itu, ini menjadi latar belakang peneliti untuk melakukan penelitian Analisis Kemampuan Literasi Statistis peserta AKM.

\section{Metode Penelitian}

Metode penelitian deskriptif dipilih karena sesuai dengan tujuan penelitian yaitu mendeskripsikan dan melihat gambaran dari kemampuan literasi statistis pada peserta didik yang akan mengikuti AKM di tahun 2021 ini. Adapun subjek dalam penelitian ini adalah sebanyak 45 orang calon peserta AKM yang berada dikelas XI SMK Abdurrab Pekanbaru. Waktu penelitian dilaksankan pada awal bulan September tahun 2021. Teknik pengumpulan data dilakukan dengan menggunakan instrument tes kemampuan literasi statistis dengan cakupan materi tes yaitu materi statistika. Adapun instrumen tes ini berupa 4 buah soal uraian yang diadopsi dari penelitian tentang analisis kemampuan literasi statistis peserta didik yang dilakukan oleh Fadillah \& Munandar (2021) yang telah diuji validitas, daya pembeda, dan indeks kesukarannya. Adapun indikator literasi statistis yang digunakan dalam penelitian ini dapat dilihat pada table 1 berikut:

Tabel 1.

Instrument literasi statistis

\begin{tabular}{ll}
\hline \multicolumn{1}{c}{ Indikator } & \multicolumn{2}{c}{ Definisi } \\
\hline Memahami & Kemampuan membaca berbagai \\
Konsep & bentuk data misalnya grafik dan \\
Statistika & simbol, serta memahami bagaimana \\
& kesimpulan statistik dicapai. \\
\hline Menginterpretas & Kemampuan menafsirkan data \\
ikan Data & sesuai dengan informasi yang ada \\
& dan mampu menentukan ide-ide \\
& statistika yang dapat dijadikan solusi \\
& dalam memberikan kesimpulan \\
& statistik. \\
\hline Menyajikan & Kemampuan menyajikan data \\
Data & menggunakan diagram dan grafik, \\
& serta menuliskan informasi darinya. \\
\hline Mengkomunika & Kemampuan menuliskan proses \\
sikan Proses & pengolahan data statistika secara \\
Pengolahan & sistematis.
\end{tabular}

Data

Sumber : (Fadillah and Munandar 2021)

Kemudian teknik analisis data yang digunakan dalam penelitian ini mengacu pada teknik analisis data menurut Miles dan Huberman (Sugiyono, 2015) yang dilakukan dengan Langkah-langkah yaitu reduksi data, pemaparan data dan penarikan kesimpulan. Selanjutnya skor tes kemampuan literasi statistis peserta didik dikelompokkan berdasarkan kategori rendah, sedang, dan tinggi. Adapun kriteria pengelompokan kemampuan literasi statistis peserta didik mengacu pada ketentuan menurut Arikunto (2013) yang disajikan pada table 2 dengan keterangan skor tes peserta didik $(x)$, skor rata-rata $(\bar{x})$ dan standar deviasi $(s)$ adalah 
JURNAL GANTANG. September 2021; VI(2): 177 - 183

p-ISSN. 2503-0671

e-ISSN. 2548-5547

sebagai berikut:

Tabel 2.

Kriteria pengelompokkan kemampuan literasi statistis

\begin{tabular}{cc} 
Kriteria Nilai & Kategori \\
$x>\bar{x}+s$ & Tinggi \\
$\bar{x}-s<x<\bar{x}+s$ & Sedang \\
$x<\bar{x}-s$ & Rendah \\
\hline
\end{tabular}

\section{Hasil dan Pembahasan}

Data hasil tes kemampuan literasi statistis yang diperoleh dalam penelitian ini dianalisis dengan memberikan skor berdasarkan rubrik indikator kemampuan literasi statistis. Table 3 menyajikan data hasil tes kemampuan literasi statistis terhadap 45 subjek penelitian.

Tabel 3.

Deskripsi hasil tes literasi statistis

\begin{tabular}{ccccc}
\hline $\begin{array}{c}\text { Jum- } \\
\text { lah Sis- } \\
\text { wa }\end{array}$ & $\begin{array}{c}\text { Nilai } \\
\text { Mini- } \\
\text { mal }\end{array}$ & $\begin{array}{c}\text { Nilai } \\
\text { Mak- } \\
\text { simal }\end{array}$ & $\begin{array}{c}\text { Rata- } \\
\text { rata }\end{array}$ & $\begin{array}{c}\text { Stan- } \\
\text { dar } \\
\text { Devia } \\
\text { si }\end{array}$ \\
\hline 45 & 21 & 100 & 57.14 & 22.68 \\
\hline
\end{tabular}

Berdasarkan tabel 3 terlihat bahwa secara keseluruhan rata-rata nilai yang diperoleh adalah 57.14. Nilai rata-rata tes kemampuan literasi statistis ini masih rendah jika dibandingkan dengan nilai KKM yang ada di Sekolah tersebut yaitu 75. Selanjutnya, akan dilakukan pengkategorian peserta AKM berdasarkan tes kemampuan literasi statistis (tinggi, sedang, dan rendah). Adapun hasil presentase kategori pengelompokan peserta didik ditampilkan pada Tabel 4. berikut:

Tabel 4.

Presentase kriteria pengelompokkan kemampuan literasi statistis

\begin{tabular}{cccc}
\hline $\begin{array}{c}\text { Kate } \\
\text { gori }\end{array}$ & Kriteria Nilai & $\begin{array}{c}\text { Jumlah } \\
\text { Sis } \\
\text { Wa }\end{array}$ & $\begin{array}{c}\text { Present } \\
\text { ase (\%) }\end{array}$ \\
\hline $\begin{array}{c}\text { Ting } \\
\text { gi }\end{array}$ & $x>79.82$ & 11 & 24.44 \\
\hline Sedang & $34.46<x \geq 79.82$ & 29 & 64.44 \\
\hline $\begin{array}{c}\text { Ren } \\
\text { dah }\end{array}$ & $x \leq 34.46$ & 5 & 11.11 \\
\hline
\end{tabular}

Berdasarkan Tabel 4. diatas, kriteria pengelompokkan kemampuan literasi statistis dari peserta AKM didapatkan bahwa kategori dengan kemampuan sedang memiliki jumlah peserta paling banyak yaitu berjumlah 29 orang

dengan persentase $64.44 \%$. Dan untuk kategori kemampuan tinggi terdapat 11 orang dengan presentase $24.44 \%$. Kemudian pada kategori rendah terdapat 5 peserta dengan persentase $11.11 \%$. Selanjutnya Untuk mengetahui nilai rata-rata kemampuan literasi statistis pada setiap indikator disajikan dalam Tabel 5 berikut.

Tabel 5 .

Rata-rata hasil tes literasi statistis setiap indikator

\begin{tabular}{lcc}
\hline \multicolumn{1}{c}{ Indikator } & $\begin{array}{c}\text { Rata- } \\
\text { rata }\end{array}$ & Kategori \\
\hline Memahami konsep statistika & 58 & Sedang \\
\hline Menginterpretasikan data & 53 & Sedang \\
\hline Menyajikan data & 59 & Sedang \\
\hline $\begin{array}{l}\text { Mengkomunikasikan proses } \\
\text { pengolahan data }\end{array}$ & 59 & Sedang \\
\hline
\end{tabular}

Persentase nilai rata-rata dari setiap indikator kemampuan literasi statistis masih tergolong sedang. Rata-rata terendah yaitu pada indikator kedua denga rata-rata 53 dan rata-rata tertinggi pada indikator ketiga dan keempat dengan rata-rata 59.

Berikut analisis jawaban siswa dari masing-masing indikator kemampuan literasi statistis:

\section{Indikator 1 (Memahami konsep statistika)}

Indikator dari soal ini adalah siswa mampu membaca berbagai bentuk data misalnya grafik dan symbol, serta memahami bagaimana kesimpulan statistik dicapai. Dari hasil analisis jawaban siswa untuk indikator pertama dikategorikan sedang dengan nilai rata-rata 58. Berikut deskripsi kemampuan siswa pada indikator pertama untuk soal nomor 1 .

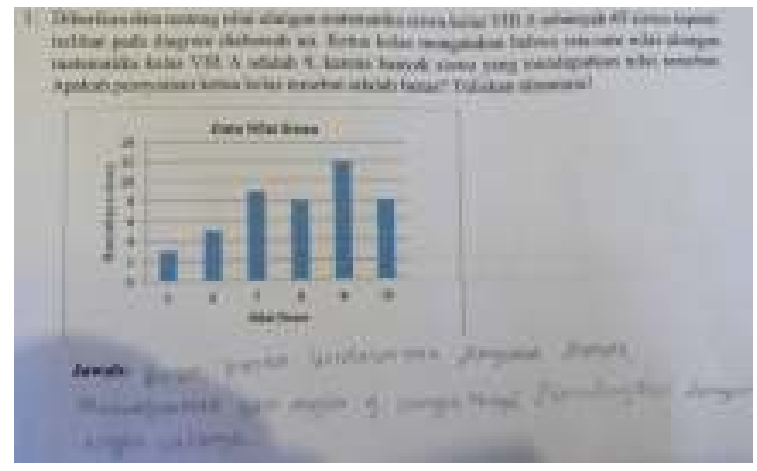

Gambar 1. Kemampuan memahami konsep statistika

Gambar 1 diatas merupakan jawaban salah satu siswa yang belum mampu memenuhi indikator tersebut. Pada gambar 1 terlihat bahwa 
siswa masih belum bisa membaca grafik dengan benar sehingga salah menyimpulkan informasi yang diberikan. Siswa tersebut beranggapan bahwa nilai 9 adalah nilai rata-rata karena grafiknya paling tinggi, padahal seharusnya untuk mencari rata-rata pada soal tersebut harus menggunakan rumus jumlah nilai data dibagi dengan banyaknya data. Terdapat 10 siswa yang belum mampu membaca grafik dengan benar, 14 siswa sudah mampu membaca grafik dengan benar tapi masih salah dalam membuat kesimpulan, sedangkan 21 siswa mendapatkan skor sempurna.

\section{Indikator 2 (Menginterpretasikan Data)}

Indikator dari soal ini adalah siswa mampu menafsirkan data sesuai dengan informasi yang ada dan mampu menentukan ide-ide statistika yang dapat dijadikan solusi dalam memberikan kesimpulan statistik. Dari hasil analisis jawaban siswa untuk indikator kedua dikategorikan sedang dengan nilai rata-rata paling rendah dari semua indikator yaitu 53. Berikut deskripsi kemampuan siswa pada indikator kedua untuk soal nomor 2 .

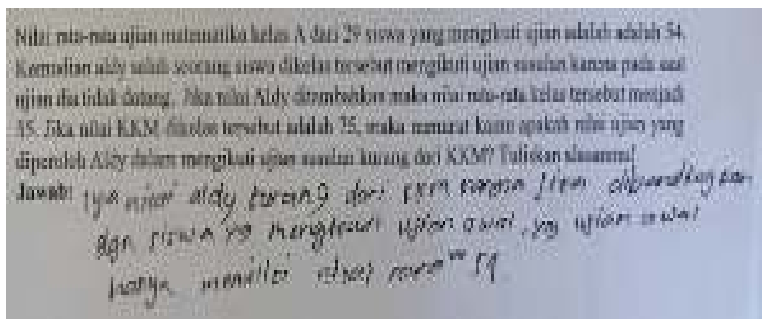

Gambar 2. Kemampuan menginterpretasikan data

Gambar 2 diatas merupakan jawaban salah satu siswa yang belum mampu memenuhi indikator tersebut. Pada gambar 2 terlihat bahwa siswa masih belum bisa menafsirkan data dengan baik. Hal ini terlihat dari jawaban siswa yang hanya memperhatikan selisih rata-rata sebelum dengan sesudah digabung. Padahal seharusnya siswa tersebut mencari terlebih dahulu nilai Aldy sebelum memutuskan kesimpulan apakah nilai Aldy tersebut kurang dari KKM. Terdapat 22 siswa yang belum mampu menafsirkan data dengan benar, dan 1 siswa sudah mampu menafsirkan data dengan benar tapi masih salah dalam membuat kesimpulan, sedangkan 22 siswa mendapatkan skor sempurna.

\section{Indikator 3 (Menyajikan Data)}

Indikator dari soal ini adalah siswa mampu menyajikan data mengguakan diagram atau grafik, serta menuliskan informasi darinya. Dari hasil analisis jawaban siswa untuk indikator ketiga dikategorikan sedang dengan nilai rata-rata 59. Berikut deskripsi kemampuan siswa pada indikator ketiga untuk soal nomor 3.



Gambar 3. Kemampuan menyajikan data

Gambar 3 diatas merupakan jawaban salah satu siswa yang belum mampu memenuhi indikator tersebut. Pada gambar 3 terlihat bahwa siswa sudah bisa menyajikan data kedalam bentuk grafik, tetapi belum mampu untuk menyimpulkan informasi dari grafik yang dibuat. Siswa tersebut menyimpulkan penjualan masker mengalami pelonjakan tertinggi hanya melihat dari kapan grafik tersebut berada pada titik tertinggi. Padahal seharusnya untuk melihat kapan penjualan masker mengalami penlonjakan tertinggi dilihat dari ruas garis yang tertinggi dari grafik tersebut. Beberapa siswa juga keliru dalam membuat skala grafiknya. Terdapat 16 siswa yang sudah mampu menyajikan data kedalam bentuk grafik dan menyimpulkan informasi dari grafik tersebut, 6 siswa sudah mampu menyajikan data kedalam bentuk grafik tetapi belum mampu menyimpulkan informasi didalamnya, 20 siswa sudah mampu menyajikan data dalam bentuk grafik tetapi masih belum tepat dalam membuat skalanya, dan 2 siswa tidak menjawab.

Indikator 4 (Mengkomunikasikan Proses Pengolahan Data)

Indikator dari soal ini adalah siswa 
JURNAL GANTANG. September 2021; VI(2): 177 - 183

p-ISSN. 2503-0671

e-ISSN. 2548-5547

menyampaikan/menuliskan proses pengolahan data statistika secara sistematis. Dari hasil analisis jawaban siswa untuk indikator keempat dikategorikan sedang dengan nilai rata-rata 59 . Berikut deskripsi kemampuan siswa pada indikator keempat untuk soal nomor 4.

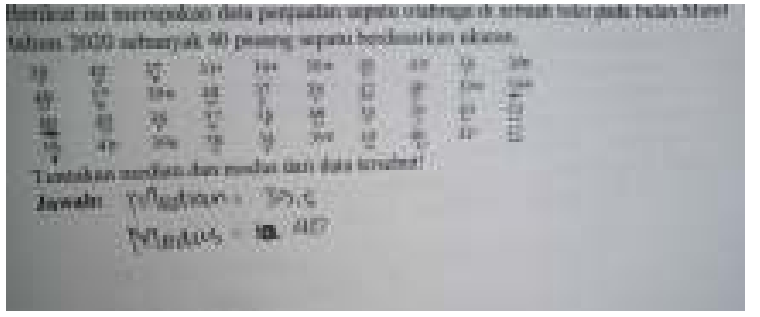

Gambar 4. Kemampuan mengkomunikasikan proses pengolahan data

Gambar 4 diatas merupakan jawaban salah satu siswa yang belum mampu memenuhi indikator tersebut. Pada gambar 4 terlihat bahwa siswa belum mampu menuliskan proses pengolahan data statistika secara sistematis, hal ini terlihat dari jawaban siswa yang hanya menulis jawabannya saja. Padahal peneliti sudah mengingatkan kepada siswa untuk menuliskan Langkah-langkah penyelesaiannya. Terdapat 18 siswa yang sudah mampu menuliskan proses pengolahan data statistika secara sistematis, 7 siswa sudah mampu menuliskan proses pengolahan data statistika secara sistematis tapi masih salah dalam perhitungannya, dan 20 siswa hanya menuliskan jawabannya saja.

Secara umum hasil kemampuan literasi statistis peserta AKM yang merujuk pada indikator penelitian secara keseluruhan telah dirangkum dalam tabel berikut:

Tabel 6.

Hasil tes literasi statistis setiap indikator

\begin{tabular}{lc}
\hline \multicolumn{1}{c}{ Indikator } & Presentase \\
\hline Memahami konsep statistika & 46.67 \\
\hline Menginterpretasikan data & 57.78 \\
\hline Menyajikan data & 35.56 \\
\hline $\begin{array}{l}\text { Mengkomunikan proses pengolahan } \\
\text { data }\end{array}$ & 40 \\
\hline
\end{tabular}

Berdasarkan tabel 6 hasil analisis kemampuan literasi statistis peserta AKM memperoleh persentase yang masih rendah disetiap indikatornya. Kemampuan peserta AKM pada indikator menginterpretasikan data memiliki

persentase terbesar, yaitu $57.78 \%$. Dan pada indikator menyajikan data memperoleh persentase paling rendah yaitu $35.56 \%$. Rendahnya pencapaian skor peserta AKM dalam tes kemampuan literasi statistis sejalan dengan penelitian Maryati and Priatna (2018) yang menunjukkan perolehan persentase tiap indikatornya masih rendah, yang disebabkan karena peserta AKM masih belum mampu menguasai pemahaman konsep yang baik dan mengalami kekeliruan dalam menyelesaikan permasalahan. Salah satu unsur penting dalam mempelajari materi matematika adalah pemahaman konsep matematis (Gusmania and Agustyaningrum 2020). Selain itu, salah satu upaya agar siswa mempunyai kemampuan literasi statistis yang bagus adalah dengan mengajarkan analisis data statistika kepada siswa sedini mungkin. Minimal siswa mampu mengolah data, menginterpretasikan data stattistika dalam bentuk tabel, grafik, dan diagram, serta mampu membaca dan menerjemahkan data yang disajikan dalam bentuk tabel, grafik, dan diagram (Abdullah and Suhartini 2017).

Berkaitan dengan beberapa masalah dan kesulitan peserta didik dalam menjawab soal literasi statistis tersebut maka perlu adanya perhatian lebih lanjut bagi guru dalam mengembangkan kemampuan literasi statistis peserta didik. Karena kemampuan ini merupakan salah satu kemampuan yang diperlukan oleh peserta AKM dalam menjawab soal-soal AKM yang berhubungan dengan statistika. Disamping itu, hal ini juga bertujuan bagi sekolah dalam memperbaiki mutu sekolah, karena salah satu tujuan dari pelaksanaan AKM adalah untuk mengukur mutu dari satuan Pendidikan (Pusmenjar 2021).

\section{Kesimpulan}

Berdasarkan hasil analisis dan pembahasan yang telah dipaparkan di atas, maka dapat ditarik kesimpulan bahwa kemampuan literasi statistis peserta AKM SMK Abdurrab Pekanbaru masih rendah. Hal ini terlihat dari rata-rata nilai tes kemampuan literasi statistis yang diperoleh yaitu 57.14 yang masih jauh dari KKM yang telah 
ditetapkan di Sekolah tersebut yaitu 75. Dimana persentase hasil kemampuan literasi statistis pada indikator memahami konsep matematika sebesar $46.67 \%$, indikator menginterpretasikan data sebesar $57.78 \%$, indikator menyajikan data sebesar $35.56 \%$, dan indikator mengkomunikasikan proses pengolahan data sebesar $40 \%$. Rendahnya indikator kemampuan literasi statistis disebabkan karena sebagian peserta didik masih belum dapat memahami konsep statistika dengan baik sehingga tidak mampu menyajikan data dan memberikan kesimpulan statistik dengan tepat.

\section{Referensi}

Abdullah, Anis, A., \& Suhartini, S. (2017). Meningkatkan kemampuan berpikir kritis melalui pembelajaran statistika berbasis pendidikan politik di lingkungan sekolah. Jurnal Gantang 2(1):1-9. doi: 10.31629/jg.v2i1.63.

Andriatna, R., Kurniawati, I., \& Wulandari, A.N. (2021). Profil kemampuan literasi statistik mahasiswa calon guru matematika. FIBONACCI, 7(1), 19-28.

Fadillah, F., \& Munandar, D. M. (2021). Analisis kemampuan literasi statistis dalam pembelajaran matematika di masa pandemi. Jurnal Pembelajaran Matematika Inovatif, 4(5):1157-68. https://doi.org/ 10.22460/jpmi.v4i5.1157-1168.

Fitni, Roza, Y., \& Maimunah. (2020). Analisis kesalahan siswa berdasarkan Newman pada materi statistika ditinjau dari gaya belajar. Ilmu Pendidikan: Jurnal Kajian Teori Dan Praktik Kependidikan 5(1):1-10.

Gal, I. (2002). Adult's statistical literacy: meanings, compenents, responsibilities. International Statistical Review, 70 (1), 125.

Gusmania, Y., \& Agustyaningrum, N. (2020). Analisis pemahaman konsep matematis mahasiswa pada mata kuliah trigonometri. Jurnal Gantang 5(2):123-32. https://doi.org/10.31629/jg.v5i2.2493.

Kemendikbud. (2020). Adaptasi pembelajaran berorientasi literasi dan numerasi. http://ditpsd.kemdikbud.go.id/upload/filema nager/buku/file/Panduan/Arah\%20Kebijaka n\%20Adaptasi\%20Pembelajaran.pdf

Maryati, I., \& Priatna, N. (2018). Analisis kemampuan literasi statistis siswa Madrasah Tsanawiyah dalam materi statistika. Journal of Medives: Journal of Mathematics Education IKIP Veteran Semarang, 2(2), 205-212. https://doi.org/ 10.31331/medives.v2i2.640.

Pusmenjar. (2021). Asesmen nasional - tahun 2021.Https://Anbk.Kemdikbud.Go.Id/\#tenta ng. Retrieved January 20, 2022 (https://anbk.kemdikbud.go.id/\#tentang).

Pusmenjar. (2021). Contoh soal AKM. [Online] Tersedia: https://pusmenjar. kemdikbud.go.id/akm/ [01 September 2021]

Rumsey, D. J. (2002). Statistical literacy as a goal for introductory statistics courses. Journal of Statistics Education, 10(3), 1-12.

Siskawati, F. S., Chandra, F. E., \& Irwati, T.N. (2021). Profil kemampuan literasi nukerasi di masa pandemic Cov-19. KoPeN: Konfersensi Pendidikan Nasional, 3 (101), 253-261.

Sugiyono, 2015. Metode Penelitian Pendidikan (Pendekatan Kuantitatif, Kualitatif, dan $R \& D)$. Bandung: Alfabeta.

Yuniawatika, Y. (2018). Statistical literacy and its urgency for students. CoEMA:170-73. https://doi.org/ 10.2991/coema-18.2018.41. 